\title{
Pengaruh Volume Air Pada Media Terhadap Pertumbuhan Panjang Dan Berat Ikan Sidat (Anguilla bicolor bicolor)
}

\author{
Nur Taufiq SPJ ${ }^{1,2 *}$, Virda Maya Definta ${ }^{1}$, Raden Ario ${ }^{1}$ \\ ${ }^{1}$ Departemen Ilmu Kelautan, Fakultas Perikanan dan Ilmu Kelautan, Universitas Diponegoro \\ ${ }^{2}$ Pusat Studi Mitigasi dan Rehabilitasi Pesisir Universitas Diponegoro \\ Kampus Tembalang, Semarang 50275 Telp/Fax. 024-7474698 \\ Email: taufiqspj_1999@yahoo.com
}

\begin{abstract}
Abstrak
Budidaya ikan sidat (Anguilla sp.) di Indonesia baru mulai berkembang beberapa tahun belakangan meskipun ikan ini memiliki banyak prospek di berbagai negara Asia maupun Eropa. Kegiatan budidaya yang dilakukan di beberapa daerah baru pada taraf pembesaran pada kolam persawahan (earthen pond) dan hanya sebagian kecil yang menggunakan sistim resirkulasi. Penelitian ini bertujuan untuk mengetahui pengaruh volume air terhadap pertumbuhan panjang dan berat ikan sidat (Anguilla bicolor bicolor) stadia awal dari elver dengan sistim budidaya resirkulasi. Metode eksperimental digunakan dalam penelitian ini dengan Rancangan Acak Lengkap (RAL) menggunakan 3 perlakuan volume air yang berbeda (E: 942 1, F: 1413 1, dan G: 750 1). Sampling panjang dan berat dilakukan setiap 2 minggu selama 8 minggu budidaya. Hasil penelitian pertumbuhan panjang dan berat tiap Kolam menunjukkan nilai yang tidak berbeda nyata $(\alpha>$ 0.05). Pertumbuhan Mutlak (berat) pada kolam E: 33,33 g, F: 23,33 g, dan kolam G: 40,00 g, sementara pertumbuhan mutlak (panjang) pada kolam E: $8,67 \mathrm{~cm}, \mathrm{~F}: 7,67 \mathrm{~cm}$, serta kolam G: $9,50 \mathrm{~cm}$ selama 8 minggu budidaya. Hasil dari perhitungan Spesific Growth Rate (SGR) pada kolam E: 0,48; F:0,33 dan G: 0,57 \%/hari selama 70 hari budidaya. Pertumbuhan panjang dan berat ikan sidat pada percobaan ini mempunyai hubungan yang sangat kuat dengan korelasi antara 83,5 - 94,5\%. Hasil percobaan ini dapat disimpulkan bahwa pertumbuhan sidat stadia awal elver akan meningkat dengan menurunnya volume air pada kondisi suhu optimum $28 \pm 2{ }^{\circ} \mathrm{C}$.
\end{abstract}

Kata Kunci : Sidat, Anguilla bicolor bicolor, Volume Air, pertumbuhan, stadia awal elver

\begin{abstract}
The eel (Anguilla sp.) cultivation in Indonesia recently has just begun to develop, eventhough this species has so many economic prospect especially in eastern Asia and European countries. Aquaculture activities in some province (of Indoesia) still using earthen pond and only certain places which used Resirculating Aquaculure System (RAS) for racing the local eels. The aims of this study were to determine the effect of water volume on early elver of Anguilla bicolor bicolor length and weight growth and it's corelations. Experimental method was used, complitely random design with 3 treatments of different water volumes i.e. E: 942 liter, F: 1413 liter, and G: 750 l. Sampling were taken every fortnight during 8 weeks culture. The results shows that length and weght growth have no significantly different $(\alpha>0.05)$. Absolute growth (of weight) in each tank i.e. E: $33.33 \mathrm{~g}, \mathrm{~F}: 23.33 \mathrm{~g}$, and $\mathrm{G}: 40.00 \mathrm{~g}$, meanwhile the length absolute growth i.e. E: $8.67 \mathrm{~cm}, F: 7.67 \mathrm{~cm}$, and $G: 9.50 \mathrm{~cm}$. Spesific growth rate of early elver were: $E=0.48$, $F=0.33$ and $G=0.57$ ini $\% d^{-1}$ during $70 d$ culture. Length and weght growth have a tight correlation i.e. 83.5 to $94.5 \%$. The results of this study indicate that the growth of early eel (Anguilla bicolor bicolor) increased by decreasing water volume in the optimum water temperature of $28 \pm 2{ }^{\circ} \mathrm{C}$.
\end{abstract}

Keywords : Eel, Anguilla bicolor bicolor, Water Volume, Growth, Early elver.

\section{PENDAHULUAN}

Indonesia merupakan salah satu negara kepulauan terbesar di dunia. Potensi perairan indonesia ini memiliki kelimpahan sumberdaya kelautan termasuk katadromous species. Salah satu sumberdaya ini yaitu ketersediaan benih sidat Anguilla sp. yang cukup melimpah dan tersebar di sepanjang pantai selatan timur P. Jawa, pantai barat P. Sumatera, pantai timur P. Kalimantan, di sekeliling pantai P. Sulawesi, dan pantai utara

\begin{tabular}{llll}
\hline$*$ Corresponding author & http://ejournal.undip.ac.id/index.php/buloma & Diterima/Received & $: 19-06-2017$ \\
buloma.undip@gmail.com & & Disetujui/Accepted & $: 20-08-2017$
\end{tabular}


Papua. Dengan kelimpahan sumberdaya ikan ini, Indonesia berpeluang menjadi produsen sidat dunia bilamana berhasil mengembangkan budidaya baik skala kecil, menengah, maupun industri (Affandi et al., 2013).

Ikan sidat (Anguilla bicolor bicolor) bersifat katadromus, yaitu mengawali hidup (menetas dari telur) di laut, tumbuh menjadi dewasa di perairan tawar, kemudian akan kembali ke laut untuk memijah (Tesch, 2003 dalam Rovara et al., 2007). Wilayah perairan Indonesia sendiri sedikitnya diketahui ada enam jenis sidat yang mendiami perairan Indonesia yakni: $A$. borneensis, A. cebesensis, A. interioris, A. obscura, A. bicolor, dan A. marmorata. Dua jenis terakhir merupakan ikan sidat yang memiliki nilai ekonomis penting, disisi lain kedua jenis ini tersebar sangat luas dari Samudera India hingga Samudera Pasifik (Fahmi dan Hirnawati, 2010).

Potensi ikan sidat di negara Indonesia cukup besar tetapi belum banyak dimanfaatkan secara optimal. Prospek pemanfaatan, pengembangan dan pengelolaan ikan sidat di Indonesia cukup menjanjikan, baik dari sudut ekonomi (pengembangan budidaya) maupun pengembangan ilmu dan teknologi. Sejauh ini hanya Anguilla bicolor bicolor yang sudah mulai dibudidayakan di Indonesia (Haryono, 2008). Meskipun memiliki banyak prospek tetapi budidaya ikan sidat di Indonesia masih sangat terbatas dan kegiatannya hanya berupa pembesaran, hal tersebut disebabkan teknik reproduksinya yang belum dikuasai karena sifat daur hidupnya yang unik dan pertumbuhannya yang lambat. Waktu yang dibutuhkan ikan sidat untuk mencapai ukuran konsumsi 120 gram adalah 8-9 bulan masa pemeliharaan (Sasongko et al., 2007 dalam Yudiarto et al., 2012). Faktor lambatnya laju pertumbuhan ini sangat ditentukan pada kualitas pakan yang diberikan, sehingga untuk memacu pertumbuhan ikan sidat perlu disediakan pakan berprotein hewani yang tinggi karena sifat dari ikan sidat ini yaitu karnivora (Peni, 1993 dalam Subekti, 2011).

\section{METODE PENELITIAN}

Materi penelitian adalah ikan sidat stadia awal dari elver spesies Anguilla bicolor bicolor dengan berat awal 33, 45 dan 47 gr. Sebelum diberi perlakuan ikan ini telah melewati masa karantina selama 2 minggu, agar pada saat awal dilakukannya perlakuan sudah dalam kondisi yang cukup sehat dan tidak stress. Kolam yang digunakan dalam penelitian berjumlah 3 dengan volume air berbeda, pada kolam $\mathrm{G}$ menggunakan volume air 750 liter, kolam E 942 liter, dan pada kolam F memiliki volume air 1413 liter.

Metode Experimental digunakan pada penelitian ini dengan analisis data yang berasal dari pengamatan secara langsung di lapangan yang merupakan objek yang telah diteliti. Rancangan penelitian yang digunakan adalah Rancangan Acak Lengkap (RAL) dengan menggunakan 3 perlakuan dan 3 kali pengulangan (sampling). Penelitian ini menggunakan sistem resirkulasi untuk menjaga kualitas air selama penelitian. Parameter kualitas air yang diamati meliputi suhu, derajat keasaman $(\mathrm{pH})$, dan DO.

\section{Analisa Data}

Analisa data pada penelitian ini dilakukan dengan beberapa parameter uji diantaranya, Pertumbuhan Mutlak (PM) berat dan panjang dan Spesific Growth Rate (SGR). Perhitungan ini bertujuan untuk mendapatkan hasil dari pengaruh volume air terhadap pertumbuhan Ikan Sidat (Anguilla bicolor bicolor).

\section{Pertumbuhan Mutlak}

Pertumbuhan mutlak berat pada ikan sidat ini merupakan selisih dari berat akhir dan bobot awal pemeliharaan dalam kolam. Pertumbuhan mutlak ini dihitung menggunakan rumus:

$$
\mathrm{PM}=\mathrm{Wt}-\mathrm{Wo}
$$

Keterangan:

$\mathrm{PM}=$ Pertumbuhan mutlak

$\mathrm{Wt}=$ Berat rata-rata ikan pada saat akhir (gram)

$\mathrm{Wo}=$ Berat rata-rata ikan pada saat awal (gram).

\section{Spesific Growth rate (SGR)}

Spesific Growth Rate (SGR) dapat

dihitung dengan mengacu kepada rumus:

$$
\mathrm{SGR}=\frac{\operatorname{in} W_{t}-\mathrm{in} W_{0}}{t} \times 100 \%
$$

Keterangan:

SGR=Spesific Growth Rate (Laju Pertumbuhan Spesifik, \%/hari)

$\mathrm{Wt}=$ Final Body Weight (Rata-rata bobot ikan uji akhir penelitian, gram)

Wo =Initial Body Weight (Rata-rata bobot ikan uji awal penelitian, gram)

$\mathrm{t} \quad=$ Time (Lama pemeliharaan, hari).

\section{HASIL DAN PEMBAHASAN}

Penelitian yang telah dilakukan selama 8 minggu ini memperoleh hasil berupa laju pertumbuhan kolam $\mathrm{G}$, E, dan $\mathrm{F}$, pertumbuhan 
mutlak (PM), dan Spesific Growth Rate (SGR\%). Hasil ini didapat dari pengukuran tiap dua minggu sekali untuk melihat pertumbuhan pada sidat (Anguilla bicolor bicolor) dengan perbedaan volume air. Hal ini menunjukkan hasil bahwa tiap kolam memiliki nilai variabel yang berbeda baik panjang maupun berat badan.

Hasil analisis ragam terhadap panjang dan berat menunjukkan bahwa pertambahan panjang dan berat pada penelitian ini tidak berbeda nyata antar perlakuan yang telah diberikan dengan tingkat nilai signifikasi $5 \%$ atau 0,05 . Dilihat dari hasil analisis ragam tersebut pada ketiga kolam ini menunjukkan nilai signifikasi sebesar 0,549 pada panjang dan 0,358 pada berat $(\alpha>0,05)$.

Kualitas air yang baik dalam media pemeliharaan merupakan faktor yang sangat mendukung pertumbuhan ikan sidat. Oksigen terlarut (DO) selama penelitian ini berada dalam kisaran 5,9-6,1 mg/l. Kisaran oksigen tersebut sudah memenuhi persyaratan karena oksigen minimal yang dibutuhkan oleh ikan sidat sebesar 3,00 ppm (Subekti et al., 2011).

Data hasil pengukuran $\mathrm{pH}$ selama penelitian menunjukkan kisaran antara 7,1-7,7, hal tersebut sesuai dengan kisaran $\mathrm{pH}$ yang baik dan masih dalam batas normal yaitu 7-8,5 (Syahril et al., 2016). Suhu didalam ketiga kolam ini berkisar 26$30^{\circ} \mathrm{C}$, hasil yang diperoleh dari kisaran suhu ini sudah layak untuk pemeliharaan ikan sidat karena ikan sidat dapat beradaptasi pada suhu $12-31^{\circ} \mathrm{C}$ (Subekti et al., 2011).

\section{Laju Pertumbuhan Kolam G, E dan F}

Berdasarkan hasil pengamatan pada ketiga kolam ini mendapatkan nilai Laju pertumbuhan pada kolam E dengan perlakuan volume air 942 liter mengalami pertumbuhan yang cukup baik. Bobot rata-rata awal pada penelitian ini 45 gram pada kolam E, serta bobot rata-rata pada akhir penelitian pada kolam E mencapai 78 gram. Apabila dibandingkan dengan kolam $\mathrm{F}$, perlakuan volume air yang diberikan sebanyak 1413 liter ini tidak berbeda nyata dengan perlakuan yang diberikan pada kolam E. Bobot rata-rata awal yang dihasilkan pada kolam $\mathrm{F}$ yaitu 47 gram dengan bobot rata-rata akhir 70 gram, sedangkan pada kolam $G$ yang diberikan volume sebanyak 750 liter ini memiliki bobot rata-rata awal 33 gram dan 73 gram untuk bobot rata-rata akhir. Hasil ini dapat dilihat pada grafik nilai dari Laju Pertumbuhan Harian (Gambar 1).

Pertumbuhan Mutlak (PM)
Pertumbuhan dalam penelitian ini merupakan parameter yang paling penting. Pertumbuhan mutlak (PM) didapat dari pengamatan selama 8 minggu dengan pengambilan data (sampling) setiap dua minggu sekali dengan menggunakan timbangan digital untuk mengukur berat ikan sidat (Anguilla bicolor bicolor) dan mengukur panjang menggunakan papan yang dimodifikasi dengan penggaris.

Pertumbuhan mutlak pada kolam E memiliki nilai pertambahan berat 33,33 gram dengan pertambahan panjang hingga 8,67 sedangkan pada kolam $\mathrm{F}$ memiliki nilai pertambahan berat 23,33 gram dengan panjang mencapai 7,67 cm, perlakuan yang diberikan pada kedua kolam ini yaitu volume air sebesar 942 liter pada kolam E dan pada kolam F sebesar 1413 liter. Jika dibandingkan dengan pertumbuhan mutlak pada kolam $\mathrm{G}$ yang diberikan perlakuan volume air sebesar 750 liter ini terlihat jauh berbeda dengan mengalami pertumbuhan yang lebih tinggi dengan kedua kolam yang diberikan volume air lebih banyak. Kolam $\mathrm{G}$ memiliki nilai pertumbuhan mutlak sebesar 40 gram dengan panjang hingga $9,50 \mathrm{~cm}$. Data pertumbuhan mutlak (PM) ini didapat melalui perhitungan berat rata-rata akhir dikurangi dengan berat rata-rata

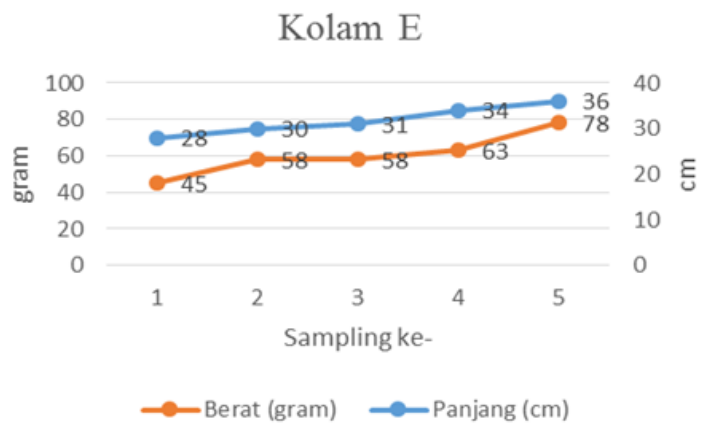

Gambar 1. Grafik Laju Pertumbuhan Kolam E.

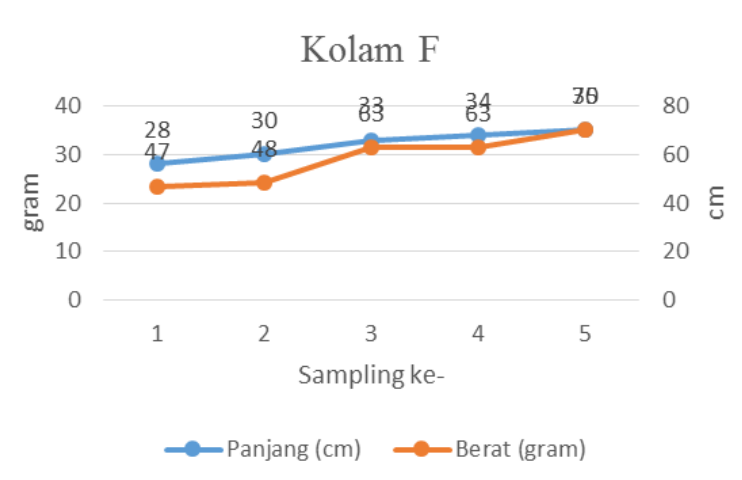

Gambar 2. Grafik Laju Pertumbuhan Kolam F 


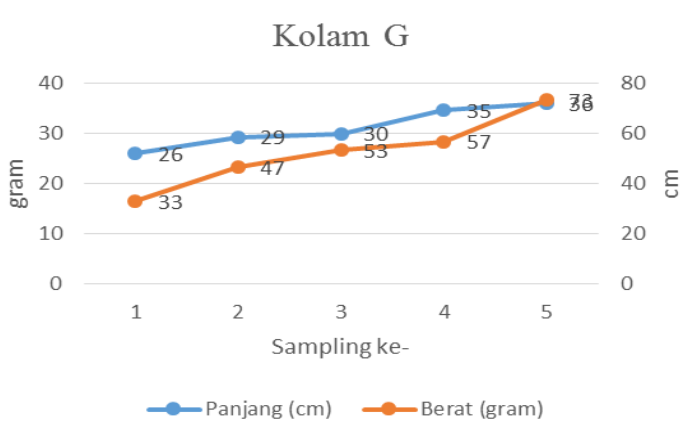

Gambar 3. Grafik Laju Pertumbuhan Kolam G.

awal dengan 3 kali pengulangan atau menggunakan 3 individu ikan sidat yang berbedabeda.

Pertumbahan mutlak (PM) pada kolam E, dan $\mathrm{F}$ menunjukkan peningkatan berat dan panjang yang relatif sehingga ditiap minggunya meningkat walaupun hanya $0,1-0,2$, gram. Hasil tersebut dapat dilihat pada histogram yang telah tersaji dalam Gambar 4 dan Gambar 5.

\section{Spesific Growth Rate (SGR)}

Data Spesific growth rate (SGR) yang diperoleh dalam penelitian ini yakni $0,48 \%$ pada kolam $\mathrm{E}$, kolam $\mathrm{F}$ memliki nilai $0,33 \%$ sehingga dapat dikatakan sebagai data tertinggi yang diperoleh dari ketiga kolam ini yaitu pada kolam $\mathrm{G}$ sebesar $0,57 \%$. Perhitungan Spesific growth rate (SGR) tidak jauh berbeda dengan perhitungan Pertumbuhan mutlak (PM), namun dalam perhitungan Spesific growth rate (SGR) dibagi dengan lama waktu selama penelitian dalam persen per hari.

Hasil penelitian ini terlihat bahwa pertumbuhan dengan kepadatan 400 ekor/kolam diperoleh hasil pertumbuhan bobot rata-rata yang berbeda, hal tersebut terjadi karena banyaknya sidat yang mati pada masa karantina setelah tebar benih dilakukan, seperti yang dijelaskan oleh Haryono (2008) bahwa pemeliharaan benih sidat pada tahap awal merupakan masa yang paling sulit dengan tingkat kelangsungan hidup sebesar $30-50 \%$.

Hasil yang diperoleh dalam Spesific growth rate (SGR) hanya pada kolam $\mathrm{F}$ yang menunjukkan lambatnya pertumbuhan, meskipun dilihat secara keseluruhan data pertumbuhan penelitian tersebut relatif normal, hal ini dapat dilihat pada Gambar 6 .

Hal ini dikarenakan pada kolam $\mathrm{F}$ yang mempunyai Volume air terbesar dibanding dengan kolam lain ( $\mathrm{E}$ dan $\mathrm{G}$ dengan volume lebih kecil) akan menyulitkan sidat stadia awal untuk mendapatkan makanan.

Namun demikian, selama pengamatan berlangsung respon benih sidat dalam masa pemeliharaan cukup baik, hal ini dikatakan karena benih sidat pada umumnya aktif dalam mencari makan. Pakan yang diberikan selama penelitian ini diberikan dalam bentuk pasta yang tentunya sebagian akan terurai dengan sendirinya dan akan menimbulkan penurunan kualitas air, maka perlu diperhatikannya selama pemberian pakan pada pagi dan sore hari untuk mengetahui bagaimana efisiensi pemanfaatan pakan oleh benih sidat dalam pemeliharaan. Apabila pemanfaatan ini dapat dilakukan dengan baik, maka pertumbuhan akan relatif lebih tinggi dan tidak adanya perbedaan yang sangat signifikan seperti hasil yang telah diperoleh.

\section{Hubungan Panjang dan Berat}

Hubungan panjang dan berat menjadi penting untuk melihat performa pertumbuhan panjang apakah diikuti dengan pertambahan berat yang signifikan. Hasil uji Regresi menunjukkan bahwa panjang dan berat badan sidat (Anguilla bicolor bicolor) memiliki hubungan yang kuat

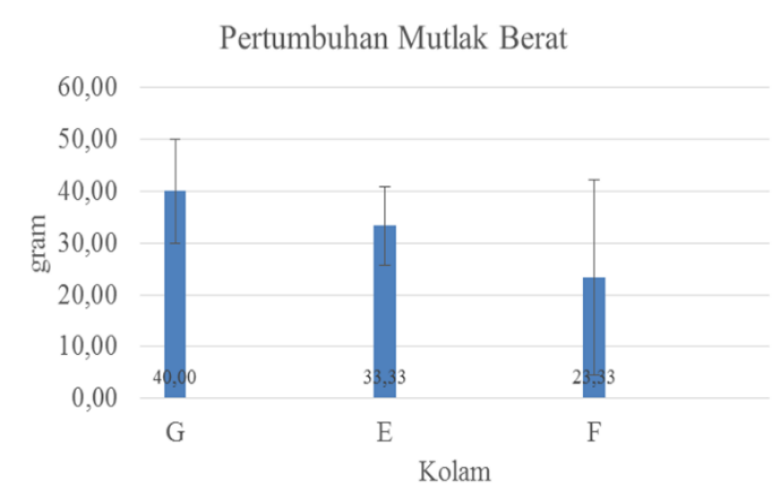

Gambar 4. Histogram Pertumbuhan Mutlak Berat selama 8 Minggu (gram).

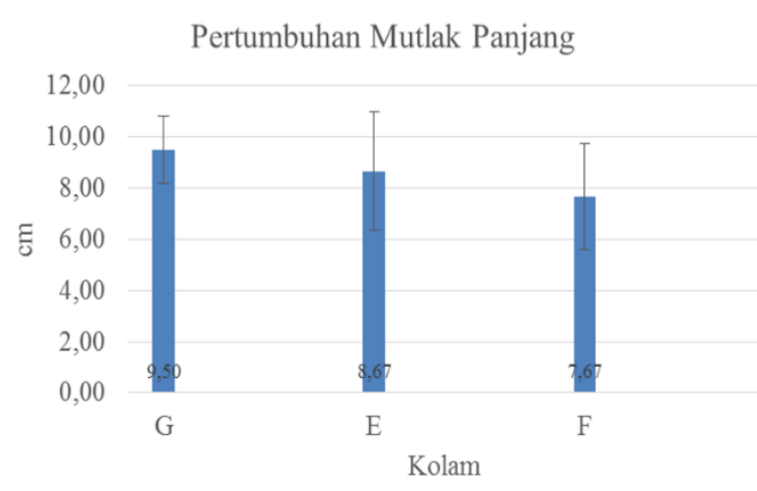

Gambar 5. Histogram Pertumbuhan Mutlak Panjang selama 8 Minggu $(\mathrm{cm})$. 


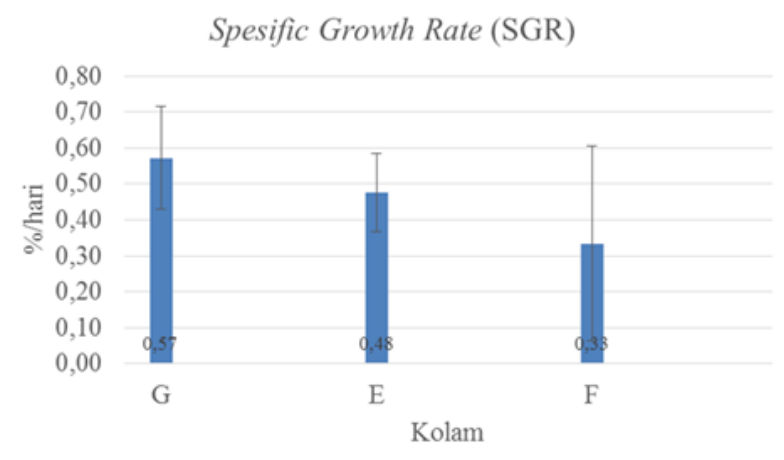

Gambar 6. Histogram Spesific Growth Rate

pada semua perlakuan Yakni dengan nilai $\mathrm{R}$ sebesar 0,945 pada Perlakuan E, F $(0,875)$ dan G $(0,835)$. Dengan demikian setiap pertambahan panjang, diikuti pertumbuhan berat dari ikan.

Penilaian panjang berat ini dilakukan untuk melihat kemampuan ikan dalam mengejar pakan yang disediakan. Taufiq-Spj et al (2017) menyatakan bahwa sebagai organisme karniforous, pertumbuhan panjang ikan sidat akan menjadikan ikan ini semakin pisciforous, sementara May dan Marshall (2008) menambahkan bahwa walaupun ikan dengan ukuran kurang dari $30 \mathrm{~cm}$, pemberian pakan parr (juvenile) salmon memberikan rangsangan pada A. anguilla untuk memangsa. Namun demikian ketiga volume air yang diberikan sebagai perlakuan tidak memberikan pengaruh yang berbeda diantara perlakuan $(\alpha>0,05)$ pada pertumbuhan panjang ikan sidat (Anguilla bicolor bicolor).

\section{KESIMPULAN}

Berdasarkan hasil dari penelitian ini menunjukkan bahwa walau tidak terdapat perbedaan nyata diantara perlakuan, namun pertumbuhan A. bicolor bicolor stadia elver awal meningkat dengan menurunnya volume air. Pertumbuhan Mutlak Berat pada kolam E: 33,33 gram, F: 23,33 gram, dan kolam G: 40,00 gram, untuk hasil dari Pertumbuhan Mutlak Panjang mendapatkan nilai sebesar $8,67 \mathrm{~cm}$ pada kolam E dan 7,67 cm pada kolam F, serta kolam G: 9,50 $\mathrm{cm}$, sedangkan hasil dari perhitungan Spesific Growth Rate (SGR) yaitu pada kolam E: 0,48; F:0,33 dan G: 0,57\%/hari. Terdapat korelasi yang kuat antara pertumbuhan panjang dan berat ikan dengan dilai korelasi antara 83,5-94,5\%.

\section{UCAPAN TERIMA KASIH}

Penulis menyampaikan terima kasih kepada semua pihak yang telah memberikan dukungan dan bantuan kepada penulis selama penelitian terutama kepada Sdr. Tri Ananto dalam menyiapkan sistim sirkulasi.

\section{DAFTAR PUSTAKA}

Affandi, R., Budiardi, T., Wahju, R.I., \& Taurusman, A.A. 2013. Pemeliharaan Ikan Sidat dengan Sistem Air Bersirkulasi (Eel Rearing in Water Recirculation System). Jurnal Ilmu Pertanian Indonesia. 18(1):5560.

Fahmi, M.R. \& Hirnawati, R. 2010. Keragaman Ikan Sidat Tropis (Anguilla sp.) di Perairan Sungai Cimandiri, Pelabuhan Ratu, Sukabumi. Prosiding Forum Inovasi Teknologi Akuakultur. Badan Penelitian dan Pengembangan Kelautan dan Perikanan. Jakarta.

Haryono. 2008. Sidat, Belut Bertelinga: Potensi dan Aspek Budidayanya. Bidang Zoologi, Pusat Penelitian Biologi-LIPI. Fauna Indonesia. 8(1):22-26.

May, D. \& Marshall, S. 2008. The 'West Sutherland Elver Survey' project, Communities Project for Highland Biodiversity Ref: CPHB12

Rovara, O., Setiawan, I.E. \& Amarullah, M.H. 2007. Mengenal Sumberdaya Ikan Sidat. BPPT-HSF, Jakarta.

Sasongko, A., Purwanto, J., \& Mu'minah, S.A. 2007. Sidat, Panduan Agribisnis, Penangkapan, Pendederan dan Pembesaran. Penebar Swadaya. Jakarta.

Subekti, S., Prawesti, M., \& Arief, M. 2011. Pengaruh kombinasi pakan buatan dan pakan alami cacing sutera (Tubifex tubifex) dengan persentase yang berbeda terhadap retensi protein, lemak dan energi pada ikan sidat (Anguilla bicolor). J. Kelautan: Indo. J. Mar. Sci. Technol. 4(1):90-95.

- Syahril, M., Tantu, F. Y. \& Ndobe, S. 2016. Distribusi Spasial dan Temporal Ikan Sidat (Anguilla sp.) yang Bermigrasi Kehulu di Sungai Tinombo Kabupaten Parigi Moutong. J. Sains Teknol. Tadulako., 5(2):28-34.

Taufiq-Spj, N., Sunaryo, S., Wirasatriya, A., \& Sugianto, D. N. (2017, February). The Use of Water Exchange for Feeding Rate and Growth Promotion of Shortfin Eel Anguilla bicolor bicolor In Recirculating Water System. IOP Conference Series: Earth and Environmental Science 55(1):012015. doi: 10.1088/1755-1315/55/1/01201 